\title{
The Influence of Electromagnetic Wave Originating from WiFi Router on Water Viscosity
}

Streszczenie. Celem prezentowanej pracy było sprawdzenie, czy mikrofale generowane przez typowy router WiFi wpływają na lepkość wody, jak sugeruja niektórzy autorzy. Pomysł bazuje na obserwacji ruchu magnetycznych nanoczastek pod mikroskopem w obecności mikrofal i bez nich. Ruch nanocząstek w polu widzenia mikroskopu był wymuszony przez zastosowanie stałego pola magnetycznego. Porównywano prędkości nanocząstek w obecności pola elektromagnetycznego $i$ bez niego.

Abstract. The aim of the study was to investigate if microwaves generated by a typical WiFi router influence the viscosity of water, as suggested by some authors. The idea relies on the microscopic observation of magnetic nano-beads motion with and without microwave irradiation. A static magnetic field was applied to force the nano-beds movements in the microscope field of view (FOV). The nano-beds velocities under microwave irradiation were compared to their velocities without the electromagnetic stimulation (Wpływ fali elektromagnetycznej generowanej przez router WiFi na lepkość wody).

Słowa kluczowe: mikrofale, lepkość wody, nanoczastki, efekty nietermiczne. Keywords: microwaves, water viscosity, nano-beads, non-thermal effects.

\section{Introduction}

The influence of electromagnetic fields (EMF) in the microwave range on human health meets a rising interest parallel to the rising importance of wireless communication technologies [1].

This research stays in line with recent interest in the impact of electromagnetic radiation on living organisms. Many studies focus on measurements of electromagnetic fields in the environment [2-4]. The field parameters distributions can be measured but can be also simulated $[5,6]$. Another problem is how the EMF influences human health. Some researchers consider human physiology [7-9] but the direct impact of potentially harmful factors cannot be studied in human research in all aspects. Therefore also the animal [10] and cellular models are often applied [11]. Our work concentrates on an simpler environment, i.e., water with suspended inorganic nano-objects.

High intensity microwaves are able to increase tissue temperature and this effect is well known and widely accepted. Some researchers claim that low intensity microwaves are influencing living organisms also in a nonthermal way and that these non-thermal effects could possibly cause some harmful results [1].

The non-thermal mechanism of how the EMF could influence the matter is unknown. This is the main cause why the harmful or beneficial role of EMF on humans cannot be unequivocally confirmed [12].

One of the possible explanation of non-thermal microwave impact on living organisms is that microwave irradiation affects the hydrogen bonds between polar water particles [13]. As the effect the water viscosity, or the diffusion coefficients for different meaningful agents, can be changed by microwave interaction.

We propose relatively simple experiment allowing the investigation of the non-thermal effects of EMF on water viscosity. The studies of magnetic nano-beads movements within distillated water with or without EMF irradiation would allow to confirm, if the viscosity of water changes in the presence of microwaves. The proposed method is similar to the Stokes method of water viscosity measurements, but instead of gravity the static magnetic field is used for nanobeads driving within the microspore's field of view (FOV).

It is worth noting that magnetic nanoparticles, and electromagnetic fields themselves, are becoming a popular tool for investigating living cells [14-16]. It is then useful to investigate, how the external fields impact the behavior of such probes in simpler settings, as the one described below.

\section{Materials and methods}

Experiments were performed with the sample containing the magnetic nano-beads in four setups: (1) sample without the static magnetic field (SMF) and without microwaves irradiation (also denoted here as EMF), (2) sample without SMF and with EMF, (3) sample within SMF and without EMF and finally (4) sample in both SMF and EMF. All parameters concerning particular setups will be denoted by the superscript as follows: (1) - "w", (2) - "r", (3) - "m" and (4) - "mr".

$2 \mathrm{ml}$ of distilled water solution of $100 \mathrm{~nm}$ in diameter fluorescent magnetic nano-beads (nano-screenMAG, Chemicell) was prepared and placed under the microscope ( $5 \mu \mathrm{l}$ bead solution in $1.995 \mathrm{ml}$ water).

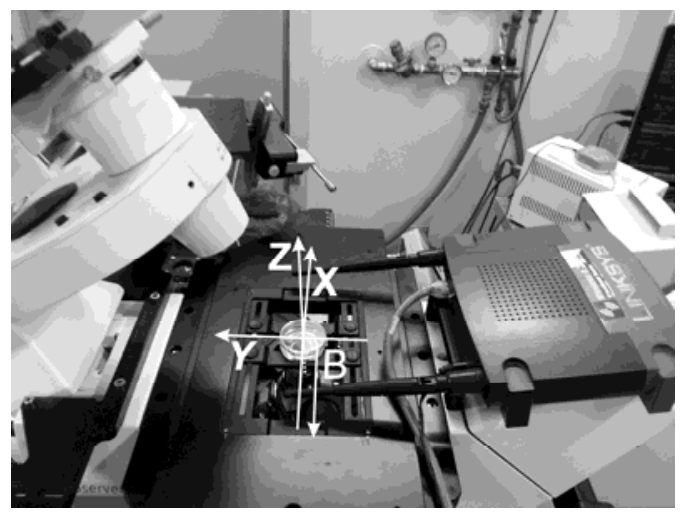

Fig. 1. The view of experimental setup. Sample placed within the standard microspore sample holder which was exchanged for a specially designed one, equipped with two magnets. The router used in experiment visible on the right site. The coordinating system and the static magnetic field direction are also shown

Zeiss Axio Observer Z1 inverted microscope (10x and 40x/0.6 Korr M27 objectives) was used (Fig. 1). A specially designed samples holder for experiments with SMF was developed and prepared with the use of a 3D printer (Fig. 2). Two neodymium magnets were glued to the holder in 
order to obtain SMF. Magnetic field induction in the center of sample holder was about $90 \mathrm{mT}$. Magnetic field induction was measured with the use of ASONIK SMS-102 meter. Magnetic field vector was parallel to the microscope FOV $X$ axis and was directed towards the negative coordinates (Fig. 1).

WRT54GL Wi-Fi Wireless-G Broadband router was used as the EMF source. It was operating with the frequency of $2.4 \mathrm{GHz}$. A huge amount of data were transferred from/to the laptop to/from the computer placed outside the laboratory with the use of properly configured router. The router was downloading and uploading data during the experiment in order to force realistic microwave irradiation. Both router antennas were directed horizontally on both sides of the sample (Fig. 1). The distance between the antennas and the observed samples was about $6 \mathrm{~cm}$. The antennas were directed along the $Y$ axis. The EMF strength was not measured during the experiment but accordingly to the router manuals the maximal output power was stated by the producer as $18 \mathrm{dBm}(63 \mathrm{~mW})$.

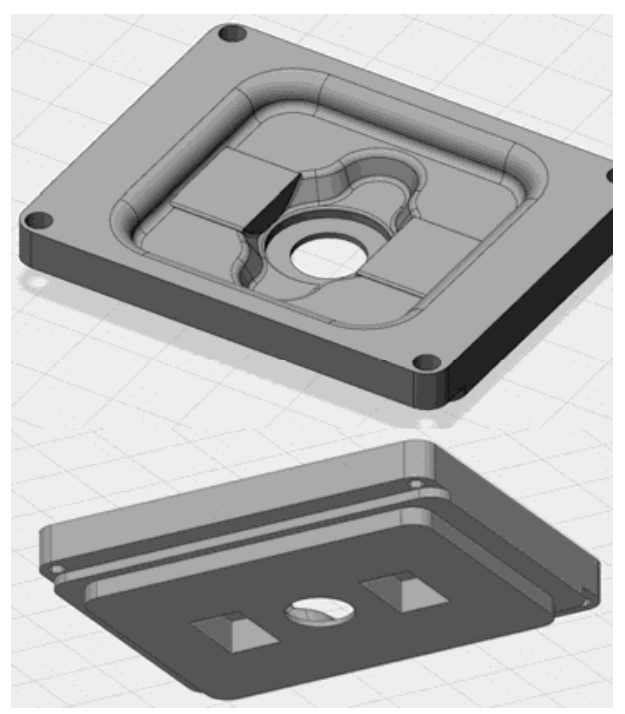

Fig. 2. A project of samples holder developed for the experiments with the static magnetic fields. Top and bottom views. The two cuboid holes visible on the bottom are devoted for neodymium magnets

The temperature of the sample was controlled by a thermocouple thermometer and stabilized during the whole experiment on the level of $21.6 \pm 0.1{ }^{\circ} \mathrm{C}$ by the microscope equipment.

Experiment was performed inside the Faraday's cage in order to avoid the influence of electromagnetic smog.

The microscope's camera acquired frames every $50 \mathrm{~ms}$ and about 2000 frames were acquired for every experimental setup. The EMF was switched on and off every $90 \mathrm{~s}$

The acquired series of frames were imported to ImageJ (by Wayne Rasband, National Institutes of Health, USA) and converted to the format accepted by Tracker software (Open Source Software by Douglas Brow). Nano-beads positions were tracked and their frame-to-frame velocities were calculated. First the $\mathrm{X}$ and $\mathrm{Y}$ velocity components were calculated and subsequently the absolute velocity values. More than 2000 frame-to-frame velocities were determined for about 25 nano-beads for every experimental setups. This is because a particular nano-bead stays only for a moment in the microscope focal plane. Even for the experiment without SMF and EMF they are still falling down because of gravity.
Velocities and their components distributions were collected and analyzed. The averages and standard deviations were calculated. The normality of distributions was checked with Shapiro-Wilk method while the variance uniformity was tested with Levene'a test. The velocity components, as well as the absolute velocities were compared with Kruskal-Wallis test. The significance level was set in all statistical test as 0.05 .

All statistical analyses were performed in Statgraphics Centurion XVI (Statgraphics Technologies, Inc., The Plains, Virginia, US).

\section{Results}

Figure 3 shows the sample data frames acquired in different time moments. The results of velocity calculations are shown in Table 1. Statistical analyses shown that the differences of absolute velocities are statistically meaningful for all four experimental setups $\left(V_{w}, V_{r}, V_{m}, V_{m r}\right)$. The $X$ and $Y$ velocities components were also compared. There are only 5 pairs which did not differ statistically: $V_{w}{ }^{x}-V_{r}{ }^{x}, V_{w}{ }^{x}-$ $\mathrm{V}_{\mathrm{r}}^{\mathrm{y}}, \mathrm{V}_{\mathrm{w}}^{\mathrm{y}}-\mathrm{V}_{\mathrm{r}}^{\mathrm{x}}, \mathrm{V}_{\mathrm{r}}^{\mathrm{x}}-\mathrm{V}_{\mathrm{r}}^{\mathrm{y}}, \mathrm{V}_{\mathrm{m}}^{\mathrm{y}}-\mathrm{V}_{\mathrm{mr}}^{\mathrm{y}}$.

Sample temperature did not change within the temperature range defined by the precision of temperature measurements $\left( \pm 0.1^{\circ} \mathrm{C}\right)$.

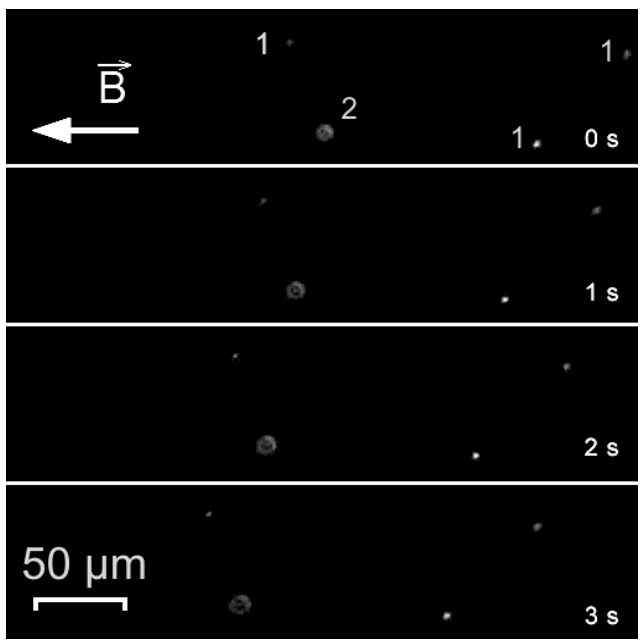

Fig. 3. An example of image data collected in the experiments. Three frame fragments are shown separated with $1 \mathrm{~s}$ time period in order to show the nano-beads movements in the static magnetic field. The white dots denoted by (1) are the nano-beds staying in the focal distance, while the one denoted with (2) stays out of the microscope focal plane.

Table 1. The results of velocity calculations. Parameters denoted with superscript mean appropriately $X$, and $Y$ velocity components. Parameters without the superscript are the average absolute velocities. The subscripts denote the experimental setup: w - no static magnetic field, and no microwave irradiation, $r$ - no static magnetic field and microwave radiation present, $m$ - experiment with magnetic static field but without EMF, mr - both, static magnetic field and microwaves radiation are present.

\begin{tabular}{|c|c|c|c|c|}
\hline $\begin{array}{l}\text { Static } \\
\text { magnetic } \\
\text { field }\end{array}$ & $\begin{array}{l}\text { Electromagnetic } \\
\text { irradiation }\end{array}$ & $\begin{array}{l}\text { Symbols } \\
\text { used }\end{array}$ & $\begin{array}{l}\text { Average } \\
{[\mu \mathrm{m} / \mathrm{s}]}\end{array}$ & $\begin{array}{l}\text { Standard } \\
\text { deviation } \\
{[\mu \mathrm{m} / \mathrm{s}]}\end{array}$ \\
\hline \multirow{3}{*}{ - } & \multirow{3}{*}{ - } & $V_{w}{ }^{x}$ & 0.0 & 2.0 \\
\hline & & $V_{w}^{y}$ & -0.4 & 1.9 \\
\hline & & $V_{w}$ & 2.3 & 1.5 \\
\hline \multirow{3}{*}{ - } & \multirow{3}{*}{+} & $V_{r}{ }^{x}$ & -0.1 & 4.3 \\
\hline & & $\mathrm{V}_{\mathrm{r}}^{\mathrm{y}}$ & 0.1 & 4.6 \\
\hline & & $V_{r}$ & 3.7 & 5.1 \\
\hline \multirow{3}{*}{+} & \multirow{3}{*}{ - } & $\mathrm{V}_{\mathrm{m}}^{\mathrm{x}}$ & -12.7 & 8.5 \\
\hline & & $V_{m}^{y}$ & 1.3 & 6.8 \\
\hline & & $V_{m}$ & 14.7 & 8.1 \\
\hline \multirow{3}{*}{+} & \multirow{3}{*}{+} & $V_{m r}{ }^{x}$ & -12.4 & 14.4 \\
\hline & & $\mathrm{V}_{\mathrm{mr}}^{\mathrm{y}}$ & 1.4 & 11.8 \\
\hline & & $\mathbf{V}_{\mathrm{mr}}$ & 18.1 & 13.3 \\
\hline
\end{tabular}




\section{Discussion}

The absolute velocity values obtained in all four experimental setups differ significantly. This suggests that EMF, as well as SMF, changes the nano-beads behavior. The nano-beads are accelerated and moved by the SMF, as expected. The differences between $V_{w}$ and $V_{r}$, and also between $V_{m}$ and $V_{m r}$ are possibly the consequence of water viscosity changes due to microwaves. This finding confirms the previously reported results [13].

SMF forces the directed nano-beads movements. The direction of absolute velocities is parallel to the magnetic field induction vector. The $\mathrm{V}_{\mathrm{m}}{ }^{\mathrm{x}}$ and $\mathrm{V}_{\mathrm{mr}}{ }^{\mathrm{x}}$ components are considerably higher than $\mathrm{V}_{\mathrm{w}}{ }^{\mathrm{x}}$. Nonzero $\mathrm{V}_{\mathrm{m}}{ }^{\mathrm{y}}$ and $\mathrm{V}_{\mathrm{mr}}{ }^{\mathrm{y}}$ show that the magnetic field was not exactly parallel to the $X$ axis of the FOV. Direction's discrepancy can be caused by magnetic field heterogeneity or could be the effect of not proper microscope camera fastening. Axis correction should be performed during further experiments.

One of the interesting findings is that the standard deviations of calculated parameters are rising when the EMF is present. That means that the nano-beads movements became more chaotic and unpredictable in the presence of EMF than without it.

Unfortunately some results cause that the conclusions cannot be driven unequivocally. When the SMF and EMF are switched off, only the Brownian movements should be observed. For the Brownian movements none direction should be preferred, so $\mathrm{V}_{\mathrm{w}}{ }^{\mathrm{x}}$ and $\mathrm{V}_{\mathrm{w}}{ }^{\mathrm{y}}$ should be both equal to 0 . Statistical analysis demonstrates statistically meaningful differences between this two velocity components. The negative $V_{m}{ }^{y}$ value suggests that $-Y$ direction is favored. This suggests that the microscope's optical axis is not vertical. Nano-beads suspended in the distillated water are subjected to the gravity force. They are falling down and when the optical axis of the optical system is not vertical, the $Z$ velocity component is projected on the $X Y$ plane. This effect is not visible well in SMF because the magnetic force is much higher than the gravity. Also when the EMF is present there are no differences between $X$ and $Y$ velocity component but this is caused probably by the velocity distribution widening confirmed by standard deviations increase.

Also this direction discrepancy could easily be corrected at the results postprocesing stage if necessary, as in the case of $Z$ axis correction.

Another crucial problem is, if the observed effects, even if real, are really non-thermal in nature. The potential temperature increase could be lower than the precision of temperature measurements. It is really difficult to state it unequivocally because at the present stage of our investigations the real EMF sample exposition was not measured. Only very obscure assessment is possible under consideration that the router emits always the maximal power stated by the producer.

\section{Conclusions}

Presented data should be treated as preliminary. Despite seemingly high statistical power (more than 2000 frameto-frame trajectories) the real statistical power is not so impressive (about 25 nano-beads analyzed). Another experiment improving the statistical power will be performed.

The geometrical corrections of axes would make our findings more reliable. The corrections of geometry could be done at the data postprocessing stage of experiment but could also rely on physical corrections before experiment. The second solution seems to be better.

The geometrical corrections of axes is especially relevant, when one considers another logical step of such kind of investigations. Antenna's direction could possibly impact the result. This should be studied, as the electrical component of EMF is direction-dependent.

The presented preliminary results suggest that water viscosity could be affected by the microwaves within the non-thermal range, but further experiment are still desirable.

Autorzy: dr hab. Grzegorz Tatoń, Jagiellonian University Medical College, Faculty of Medicine, Chair of Physiology, Department of Biophysics (Bioph. Dep.), ul. Św. Łazarza 16, 31-530 Kraków, Poland, E-mail: g.taton@uj.edu.pl; mgr Daniel Dziob, Bioph. Dep., E-mail: daniel.dziob@uj.edu.pl; Aleksandra Mielnicka, Jagiellonian University, Smoluchowski Institute of Physics, E-mail: aleksandra.mielnicka@student.uj.edu.pl; dr Bartosz Lisowski, Bioph. Dep., E-mail: bartek.lisowski@uj.edu.pl; dr Tomasz Rok, Bioph. Dep., E-mail: tomasz.rok@uj.edu.pl; mgr Michał Świątek, Bioph. Dep., E-mail: mgj.swiatek@uj.edu.pl; mgr Piotr Kuterba, Bioph. Dep., E-mail: piotr.kuterba@uj.edu.pl; prof. dr hab. Eugeniusz Rokita, Bioph.Dep., E-mail: e.rokita@uj.edu.pl

\section{LITERATURA}

[1] Cucurachi S., Tamis W.L.M., Vijver M.G., Peijnenburg W.J.G.M., Bolte J.F.B., de Snoo G.R., A review of the ecological effects of radiofrequency electromagnetic fields (RF-EMF), Environmental International, 51 (2013), 116-140

[2] Bieńkowski P., Podlaska J., Pole elektromagnetyczne w środowisku - pomiary i monitoring w Polsce, Przegląd Elektrotechniczny, 93 (2017), nr.12, 71-74

[3] Sygocki W., Korzeniewska E., Sources of information in the field of electromagnetism and occupational safety: bibliometric and altmetric data, Przeglad Elektrotechniczny, 93 (2017), nr.1, 209-212

[4] Sagar S., Adem S.M., Struchen B., Loughran S.P., Brunjes M.E., Arangua L., Dalvie M.A., Croft R.J., Jerrett M., Moskowitz J.M., Kuo T., Roosli M., Comparison of radiofrequency electromagnetic field exposure levels in different everyday microenvironments in an international context, Environment Int., 114 (2018), 297-306

[5] Miaskowski A., Krawczyk A., Olchowik G., Łada-Tondyra E., Bartosiński A., A Numerical Evaluation of Electric Field and SAR Distribution Around a Titanium Implant in the Trunk of a Boy, Przegląd Elektrotechniczny, 88 (2012), nr.12b, 77-79

[6] Martens A.L., Bolte J.F.B., Beekhuizen J., Kromhout H., Smid T., Vermeulen R.C.H., Validity of at home model predictions as a proxy for personal exposure to radiofrequency electromagnetic fields from mobile phone base stations, Environmental Research, 142 (2015), 221-226

[7] Wdowiak A., Mazurek P.A., Wpływ pola elektromagnetycznego na rozród człowieka, Przegląd Elektrotechniczny, (2016), nr.1, 124-127

[8] Wdowiak A., Mazurek P.A., Oddziaływanie pola elektromagnetycznego na proces hiperaktywacji nasienia - badanie pilotażowe, Przegląd Elektrotechniczny, 93 (2017), nr.1, 221-224

[9] Pławiak-Mowna A., Korbicz J., Occupational EMF exposure and risk of breast cancer, Przegląd Elekektrotechniczny, 93 (2017), nr.1, 177-180

[10] Falcioni L., Bua L., Tibaldi E., Lauriola M., De Angelis L., Gnudi F., Mandrioli D., Manservigi M., Manservisi F., Manzoli I., Menghetti I., Montella R., Panzaschi S., Sgargi D., Strollo V., Vornoli A., Belpoggi F., Report of final results regarding brain and heart tumors in Sprague-Dawley rats exposed from prenatal life until natural death to mobile phone radiofrequency field representative of a 1.8 $\mathrm{GHz}$ GSM base station environmental emission, Environmental Research, 165 (2018), 496-503

[11] Henrykowska G., Lewicka M., Szczęsny A., Dziedziczak-Buczyńska M., Pacholski K., Buczyński A., Wpływ odległości od urzadzeń emitujących promieniowanie elektromagnetyczne na metabolizm tlenowy wybranych elementów morfotycznych krwi, Przegląd Elektrotechniczny, 90 (2014), nr.6, 192-194

[12] Gherardini L., Ciuti G., Tognarelli S., Cinti C., Searching for the perfect wave: The effect of radiofrequency electromagnetic fields on cells, International Journal of Molecular Science, 15 (2014); no4, 5366-5387

[13] Hinrikus H., Lass J., Karai D., Pilt K., Bachman M., Microwave effect on diffusion: a possible mechanism for non-thermal effect, Electromagnetic Biology and Medicine, Early Online: 1-7 (2014)

[14] Miyakoshi J., The review of cellular effects of a static magnetic field, Science and Technology of Advanced Materials, 7 (2006), no 4, 305-307

[15] Zablotskii V., Polyakova T., Lunov O., Dejneka A., How a HighGradient Magnetic Field Could Affect Cell Life, Scientific Reports, 6 (2016), 1-13

[16] Celedon A., Hale C.M., Wirtz D., Magnetic Manipulation of Nanorods in the Nucleus of Living Cells, Biophysical Journal, 101 (2011) no8, 1880-1886 